\title{
Correspondence
}

\section{India's Poverty and the Origins of African Nationalism ${ }^{1}$}

Dear Sir,

Professor Ali A.Mazrui has written a stimulating article on the relevance to African nationalism of the character and tactics of India's struggle for national liberation. The main trends of his argument may be summarized as follows:

India's united struggle against British imperialism was taken as a model by many African nationalists. But later, once the Moslem League had emerged and the consequent split in Indian politics had appeared, India ceased to be a reference model for the African struggle for freedom. However, by then the techniques of passive resistance, as developed by Gandhi, had become an example to be emulated for some African nationalists, although Professor Mazrui thinks that they have a far smaller chance of success in the African context. In India their success was due to their close relationship with asceticism which, according to him, is characteristic of the Indian style of social behaviour, which, in turn, emerges from the Hindu Weltanschauung. In Africa asceticism is less developed and hence a technique of struggle based on it has less appeal for Africans. Furthermore, in the post-independence period, the spirit of asceticism in India may be said to be hindering the cause of social revolution since the latter is ' $a$ revolution of rising materialistic expectations' (p. 67). As such, 'Indian attitudes are revealed to be insufficiently rebellious against ... hunger' (p. 68). Hence after independence India is found wanting as model for African social revolutionaries.

The underlying assumptions of Professor Mazrui's arguments seem to be the following:

(i) The ascetic impulse is a dominant feature of Hinduism and as such it largely influences Indian attitudes and behaviour.

(ii) The ascetic impulse makes a virtue of suffering and hardship (which are direct results of Indian poverty). And passive resistance being based on suffering and hardship harmonizes well with the ascetic impulse.

(iii) The Gandhian technique of passive resistance, having been widely accepted in India, has proved a success because it is in conformity with the Indian ascetic impulse.

1 In Vol. 2 No. 1 , October 1966-January 1967 we published an article by Professor Ali A. Mazrui entitled 'India's Poverty and the Origins of African Nationalism.' Professor A.K.Datta of University College, Cape Coast, Ghana, has sent us the commentary published here. 


\section{CORRESPONDENCE}

(iv) In the post-independence period, the spirit of asceticism is hindering the cause of social revolution and so India is found wanting as a model for African revolutionaries.

Each of these assumptions needs careful examination.

Much has been made of the stress laid by Hindu Weltanschauung on otherworldliness and asceticism. It is true that Hinduism, like early Christianity and Buddhism, sets considerable store by the renunciation of material pleasures and even comfort in order to attain union with the Absolute. The question to be considered here is how far the idea of renunciation governs Indian social behaviour and attitudes. To find its answer we have to go deeper into the structure of Hindu society. Hinduism is devoid of a dogma and a prophet. Having evolved in a large sub-corinent with complex social heterogeneity and over thousands of years, it has, like Proteus, assumed diverse forms to suit varying circumstances. There is, to be sure, a central corpus of ideas and practices. And when a reference is made to some peculiar or dominant Hindu idea, belief or rite, one has this central corpus in mind. This hard core which may be called the all-India aspect of Hinduism is central to Hindu India, not so much because it is the highest common denominator in the faith of every Hindu, but rather because in every region there are at least some Hindus who accept its rationale. However, below this great tradition (to use Robert Redfield's terms), many little traditions weave divergent patterns of life in which individual participants may not always be aware of the pertinence of every feature of the all-India framework. It is true that the great tradition and the many little traditions are not mutually exclusive, and that, when faced with a challenge, leaders at lower levels seek to justify their local tradition by referring to the great tradition. Further, taking a dynamic view of the situation, the great and little traditions can influence each other. Yet it remains a fact that much of the social existence of an individual is articulated through the idiom of his little tradition.

The idea of renunciation and the ascetic impulse is a feature of all-India Hinduism. In relatively closed local societies its pull is considerably weakened, although it may be a partly meaningful ideal for those who, like priests, have special access to all that goes by the name of all-India Hinduism. Furthermore, even in the all-India framework renunciation and asceticism are prescribed means for a definite objective, i.e., realization of divinity. As such, it is misleading to say that 'poverty [in India] commands both pity and moral admiration' (p. 65). It is not poverty as such but selfabnegation for a given objective that is admired. Indeed no sensible Hindu will admire a man who is poor because he is lazy. Again, renunciation and asceticism, even in the context of all-India Hinduism, are prescribed ideals only for a certain stage. The ideal Hindu life consists of four stages (dsramas), viz., (i) the period of discipline and education, (ii) the life of the 
family man and active worker, (iii) retreat for the attenuation of worldly ties, and finally, (iv) the life of a hermit. The second stage spent in the pursuit of worldly goals, adds unity and stability to the total social structure. Thus even in the framework of the great tradition its significance has never been belittled. Even when seeking union with the Absolute, a Hindu is constantly reminded of the various ways to reach God: through devotion (bhakti), knowledge (jñanna) and active work (karma). And the Gitā, which exercised a very powerful influence over Indian nationalists, repeatedly enjoins the devout to engage in active work without being bound by the ego or by the expectation of the fruits of his labours.

Bearing all this in mind, the influence of the ideas of renunciation and asceticism on the attitude and behaviour of the Hindu man in the street should not be exaggerated. It is difficult to say how far the popularity of Gandhi's leadership was due to the Hindu admiration for religious asceticism and to the identification, in the popular mind, of Gandhi's simple ways with those of a holy man (sadhu). We should not forget that one of the Indian provinces where passive resistance was eminently successful was the North Western Frontier Province (NWFP), 90 per cent of whose inhabitants were Moslem Pathan tribesmen whose martial spirit is farthest removed from ascetic self-abnegation. It is at least arguable that Gandhi's loin cloth, representing the poverty of the Indian peasant, was an attempt to highlight the identity of interests of the élite and the masses. Such attempts are not peculiar either to Gandhi or to Indian leadership. Similar attempts have been made by other Indian leaders, like Bose for instance, who did not believe either in passive resistance or in ascetic resignation. Outside India the simple life of a Ho Chi Minh, Mao-tse Tung, Julius Nyerere or Kenneth Kaunda bears ample testimony to conscious efforts made by leaders of a poor developing country not to cut themselves off from their roots.

As regards the relationship between the ascetic impulse and passive resistance Professor Mazrui's logic seems to be more tenuous. The ascetic impulse, so goes the argument, glorifies hardship and suffering. Passive resistance is based on hardship and suffering. Therefore, passive resistance is widely accepted by people who already hold the ascetic impulse in high esteem. Our contention here is that all national liberation struggles, passive or active, violent or non-violent, involve suffering and hardship. As such there is no special reason why passive resistance in particular should be accepted in a country where asceticism is highly valued. Again, it is difficult to see the pertinence of Indian poverty in the sequence of his argument. Professor Mazrui sets himself the task of examining the relevance of India's poverty to the emergence of African nationalism. In fact his note is a study of the role of passive resistance in India and its usefulness as a model for African nationalists. Unless we are prepared to assume that poverty and asceticism are somehow interconnected, the title of the note seems to be a misnomer. And should one argue that the ascetic impulse makes a virtue 


\section{CORRESPONDENCE}

(renunciation) of a necessity (material poverty), such an argument will in fact be a crude example of mechanistic determinism. To refute it we have only to indicate that ideas of renunciation and asceticism predate Indian poverty which is a contemporary phenomenon and that they were in vogue even when India's wealth was fabulous and legendary.

Next we come to the alleged success (measured in terms of popular acceptance and of its efficacy in achieving the goal of national independence) of the Gandhian technique of passive resistance. We certainly do not want to underrate the role of passive resistance in the Indian national struggle. But one tends often to overstress it. In fact, the struggle led by Ghandhi on the basis of passive resistance was only one, although a major one, of such struggles. But there were other struggles too; active protest under the leadership of Tilak in Maharashtra, Bipin Pal in Bengal, and Lajpat Rai in Punjab, armed clashes organized by the Hindustan Socialist Republican Party of North India and the two major revolutionary parties of Bengal, Anushilan and Jugantar, active resistance by trade unionists, and peasant revolts. Indeed, active and violent resistance was on the increase with the passage of time. The Quit India movement of 1942 , the struggle launched by the Indian National Army (INA) under Bose (although it operated from its base outside India), the post-second world war students' struggles, the movement for the release of the INA prisoners, the sharecroppers' movement in Bengal, the tribal peasants' (Worli) struggle in Maharashtra, hundreds of strikes by organized workers, the most important of which was the all-India Post and Telegraph employees' strike in 1946, and above all the mutiny of the Royal Indian Navy were some of the major battles fought by Indian nationalists after the outbreak of the second world war. And none of these had anything to do with passive resistance. It is fashionable these days to say that Gandhi achieved Indian independence. Without belittling his role in the Indian freedom movement, we would like to point out that British imperialism survived Gandhi's most successful movement (I920-I) by more than a quarter of a century, whereas the spate of revolutionary struggles unleashed after the I940s coupled with a favourable international situation brought out its downfall in a couple of years.

Professor Mazrui's last point is that after independence, the spirit of asceticism, being still in vogue in India, is hindering the cause of social revolution and so India is found wanting as a model for African revolutionaries. Strangely enough he himself contradicts this statement on page 66 where we are told that '... One of the differences between African and Indian responses to the famines of 1965 and 1966 has been the greater readiness of Indians to riot in the streets in protest against the famine. There seems to have been a greater spirit of ascetic resignation in the hungry African in Southern Africa than in the hungry Indian in his subcontinent'. Professor Mazrui tries to explain this by ascribing it to the greater degree of urbanization in India - an argument which poses another controversial cause-effect relationship. But whatever the reason, the fact 


\section{GOVERNMENT AND OPPOSITION}

remains that there has been stronger protest against hunger in India despite the so-called ascetic spirit. Indeed, even sädhus (holy men) who are supposed to embody the spirit of ascetic resignation, are rioting in the streets of Delhi (although for a different cause). And so it is not quite correct to say that in contemporary India because the spirit of asceticism is still strong, it is hindering the cause of social revolution. The promise of social revolution in India is yet to be fulfilled. But ascetic resignation does not seem to be the reason behind its slow progress.

Likewise I shall agree with Professor Mazrui that India has ceased to be a model for African social revolutionaries. But obviously this is not because Indians do not protest against hunger. Even a cursory glance at any Indian newspaper will confirm this point. India's failure to furnish a reference model for African social revolutionaries is rather due to the inability of the government of India to harness people's energy for nation-building and to introduce urgent reforms in Indian society and economy.

In short, Professor Mazrui in his thought-provoking article has reached the right conclusions, starting from wrong premises.

\section{Yours faithfully}

A. K. Datta 